\title{
A Case of Tracheobronchial Amyloidosis Treated with Endoscopic Debulking and External Beam Radiation Therapy
}

\author{
Therapie einer tracheobronchialen Amyloidose mit endoskopischer \\ Rekanalisation und Bestrahlung
}

Authors

Institutions
I. Firlinger ${ }^{1}$, U. Setinek ${ }^{2}$, H. Koller ${ }^{1}$, P. Feurstein ${ }^{3}$, H. Prosch ${ }^{4}$, O. C. Burghuber ${ }^{1}$, A. Valipour ${ }^{1}$

Institutions are listed at the end of article. received 13.5 .2013

accepted 15.5.2013

Bibliography

DOI http://dx.doi.org/

10.1055/s-0033-1344186

Pneumologie 2013; 67: 398-400

(c) Georg Thieme Verlag KG

Stuttgart · New York

ISSN 0934-8387

\section{Corresponding author}

PD Dr. Arschang Valipour Oberarzt,

I. Interne Lungenabteilung mit Intensivstation

Ludwig-Boltzmann-Institut für COPD und Pneumologische Epidemiologie

Otto-Wagner-Spital,

Sanatoriumstr.2.

1140 Wien

arschang.valipour@wienkav.at

\section{Abstract \\ $\nabla$}

We report on a 55-year-old patient who was admitted to hospital because of recurrent pneumonia. CT imaging provided airway narrowing and mural thickening of the distal trachea and mainstem bronchi, compatible with endobronchial polypoid, toric-shaped changes of the distal tracheal wall spreading into both the left and right bronchial system. Bronchoscopy was performed and biopsies revealed the diagnosis of tracheobronchial amyloidosis. We performed a combination of bronchoscopic debulking and consecutive external beam radiation therapy with the result of no further progression of the disease, stable endobronchial situation, and functional improvements at a follow up at 6 months.

\section{Introduction}

$\nabla$

Amyloidosis refers to a variety of conditions in which amyloid proteins are abnormally deposited in organs and/or tissues. Tracheobronchial Amyloidosis is an orphan disease, thus there are no uniform treatment recommendations.

\section{Case Report}

$\nabla$

We report on a 55-year-old man of Turkish descent who was admitted to hospital because of recurrent pneumonia. Besides a smoking history of 30 pack-years his past medical history was unremarkable.

Physical examination was entirely unremarkable. Spirometry demonstrated an (postbronchodilator) airway obstruction with a FEV1 of 1,27 L (38\% predicted), FVC 2,83 L (71\% predicted), and FEV1/FVC ratio of 54\%. Bodyplethysmography dis-

\section{Zusammenfassung \\ $\nabla$}

Wir berichten über einen 55-jährigen Patienten, der aufgrund einer rezidivierenden Pneumonie stationär aufgenommen wurde. In der Computertomographie des Thorax zeigten sich vor allem im Bereich der distalen Trachea, des rechten und linken Hauptbronchus Bronchialwandverdickungen mit polypoiden Strukturalterationen und konsekutiver Lumeneinengung der zentralen Atemwege bis in die Peripherie. Im Zuge einer Bronchoskopie wurden Zangenbiopsien der endobronchialen Veränderungen entnommen, mit dem histologischen Ergebnis einer tracheobronchialen Amyloidose. Die Behandlung erfolgte mit bronchoskopischer Rekanalisation und konventioneller Strahlentherapie mit dem zufriedenstellenden Langzeitergebnis eines rezidivfreien Intervalls und deutlicher funktioneller Verbesserung nach 6 Monaten.

closed normal total lung capacity (6,03 L, 107\% predicted) and a residual volume of 3,2 L. Laboratory results were normal. A chest CT scan revealed extensive irregular thickening of the walls of the right and left main bronchi, as well as the lobar and segmental bronchi on both sides with some calcifications. The thickening of the walls of the bronchi led to a significant narrowing of the right upper lobe and the lower lobe bronchi on both sides.

Videobronchoscopy demonstrated polypoid, toric-shaped changes of the distal tracheal wall spreading into both the left and right bronchial system up to the $4^{\text {th }}$ generation of bronchi. The observed bronchial abnormalities were leading to multilevel obstruction of the central airways bilaterally ( $\bullet$ Fig. 1 a, 1 b). Biopsies were taken. The microscopic work-up showed amorphous eosinophilic deposits in the bronchial walls. Congored staining revealed the characteristic applegreen birefringence of the amyloid deposits by 


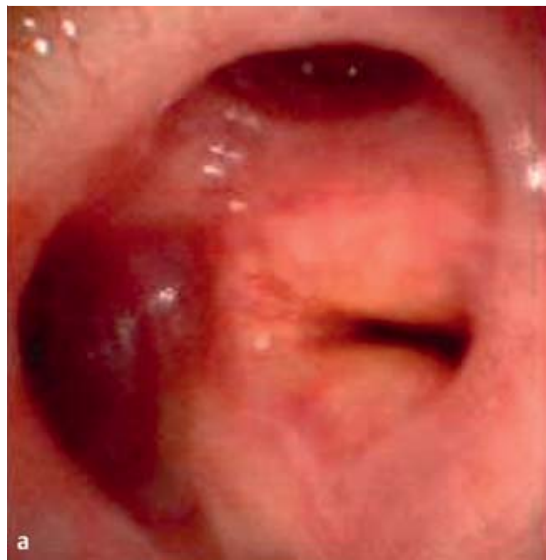

Fig. 1 a, b Endobronchial polypoid, toric-shaped changes of the distal tracheal wall spreading into the left and right bronchial system.

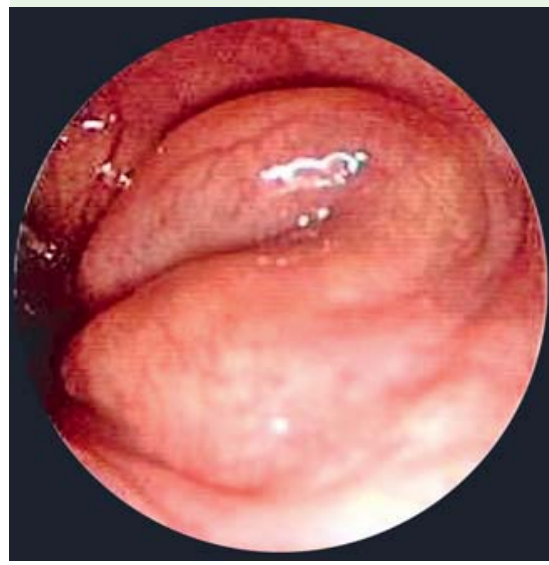

polarizing microscopy. The overlying mucosa showed squamous cell metaplasia. Between the amyloid deposits osseous metaplasia was found. Immunhistochemical analysis revealed evidence of Amyloid A. Further diagnostic testing was performed to rule out systemic involvement of amyloidosis.

Due to the extent of endobronchial manifestations we performed endoscopic resection of the amyloid tumor masses under combined rigid and flexible bronchoscopy and general anesthesia in 3 subsequent sessions within a period of 6 months. Treatments were uneventful. Besides a clinical improvement of our patient, there was evidence of functional improvements in oxygenation and spirometric testing ( $\bullet$ Table 1 ).

At a follow-up visit after 12 months computed tomography and bronchoscopy revealed progression of the tracheobronchial lesions with recurrence of bilateral airways obstruction.

Due to persistent endobronchial obstruction external beam radiation therapy (EBRT) was initiated. The dose administered was $20 \mathrm{~Gy}$ in 10 fractions of $2 \mathrm{~Gy}$ each. The volume encompassed the entire trachea beginning inferior to the vocal cords down to and including both mainstem bronchi. The radial margin was $1,5 \mathrm{~cm}$; the dose was administered in 4-field-technique. The patient tolerated the irradiation well.

Six months later, our patient underwent a repeat bronchoscopy, the endobronchial situation revealed stable disease. During a final telephone interview 24 months after radiation therapy the patient reported a good general state without further progression of the disease.
Table 1 Pulmonary Function Testing (PFT) before and after endoscopic resection.

\begin{tabular}{|c|c|c|}
\hline & $\begin{array}{l}\text { PFT before } \\
\text { endoscopic resection }\end{array}$ & $\begin{array}{l}\text { PFT after } \\
\text { endoscopic resection }\end{array}$ \\
\hline VC & 2,83I (71\% pred.) & 3,35I (85\% pred.) \\
\hline FEV1 & 1,27I (38\% pred.) & 2,26I (69\% pred.) \\
\hline FEV1/FVC & 0,45 & 0,67 \\
\hline TLC & 6,03I (107\% pred.) & 6,00 I (107\% pred.) \\
\hline RV & 3,21 & 2,651 \\
\hline DLCO & $77 \%$ & $85 \%$ \\
\hline
\end{tabular}

\section{Discussion}

$\nabla$

Localized pulmonary amyloidosis is rather rare and considered a primary form of amyloidosis. The mean age of patients with tracheobronchial amyloidosis ranges between 54 and 62 years [1-5].

While Rubinow et al [4] reported an increased prevalence of tracheobronchial amyloidosis in men, Capizzi et al [5] did not observe gender-related differences. There is some evidence of a relationship with smoking history [5].

Patients may have symptoms associated with endobronchial obstruction, such as recurrent lower respiratory tract infections, cough, rhonchi and wheezing on auscultation, hemoptysis, hoarseness, and/or stridor $[1,2,4]$.

Chest-imaging (X-ray, computed tomography) usually shows narrowing of the distal trachea and mainstem bronchi, with some postobstructive evidence of atelectasis and/or pneumonia [1, 2]. CT imaging provides quantitative assessment of airway narrowing and mural thickening, two major consequences of amyloid infiltration. [6] The presence of mural calcifications sparing the posterior tracheal membrane may be misclassified as tracheobronchopathia osteochondroplastica [6].

Endobronchial visualization of the pathology reveals submucosal shiny plaques which may result in airway obstruction. Endoscopic biopsies are needed to obtain the diagnosis [2].

The disease can progress without treatment and life threatening complications may occur [5], however, spontaneous regression has also been documented [7]. Thirty percent of patients die within 7-12 years after diagnosis [8].

Systemic medications such as colchicine, melphalan, and corticosteroids have been attempted with little or no benefit. [9]. Local treatment is indicated in the presence of symptoms due to airway obstruction. Bronchoscopic resection with forceps and laser therapy has been used in this indication [5]. The recurrence of lesions and the inaccessibility of some lesions to bronchoscopic intervention, however, is an important limitation to this technique. Repeated bronchoscopic resections are therefore often necessary [5].

Neben-Wittich and co-workers reported a series of seven patients who were treated with EBRT as the only intervention. Objective improvement was observed in 4 out of 7 patients with a $57 \%$ success rate within 1 year when using FEV1 as a surrogate. It appears that radiation therapy may change the progressive course of tracheobronchial amyloidosis [10].

The mechanism by which EBRT exerts its effects on the amyloid deposits is unclear. It is possible that radiation therapy has an effect on local plasma cells as shown in patients with multiple myeloma [11]. EBRT may further result in a local inflammatory re- 
sponse which may stop the progression of the disease, however, there is no particular evidence to support this theory.

In conclusion, we recommend considering a combination of bronchoscopic resection and consecutive external beam radiation therapy in patients with tracheobronchial amyloidosis.

\section{Conflict of interest}

The authors have no conflict of interest.

\section{Institutions}

${ }^{1}$ Department of Respiratory and Critical Care Medicine, Ludwig-BoltzmannInstitute for COPD and Respiratory Epidemiology, Otto Wagner Hospital, Vienna, Austria

${ }^{2}$ Institute of Pathology and Bacteriology, Otto Wagner Hospital, Vienna, Austria

${ }^{3}$ Institute of Radiooncology, Wilhelminenspital, Vienna, Austria

${ }^{4}$ Department of Radiology, Otto Wagner Hospital, Vienna, Austria

\section{References}

1 Hui AN, Koss MN, Hochholzer L et al. Amyloidosis presenting in the lower respiratory tract. Clinicopathologic, radiologic, immunohistochemical, and histochemical studies on 48 cases. Arch Pathol Lab Med 1986; 110 : $212-218$

2 Thompson PJ, Citron KM. Amyloid and the lower respiratory tract. Thorax 1983; 38: $84-87$

3 Utz JP, Swensen SJ, Gertz MA. Pulmonary amyloidosis. The Mayo Clinic experience from 1980 to 1993. Ann Intern Me 1996; 124: 407-413

4 Rubinow A, Celli BR, Cohen AS et al. Localized amyloidosis of the lower respiratory tract. Am Rev Respir Dis 1978; 118: 603-611

5 Capizzi SA, Betancourt E, Prakash UB. Tracheobronchial amyloidosis. Mayo Clin Proc 2000; 75: 1148 -1152

6 Prince JS, Duhamel DR, Levin DL et al. Nonneoplastic lesions of the tracheobronchial wall: radiologic findings with bronchoscopic correlation. Radiographics 2002; 22: 215-S230

7 Hof DG, Rasp FL. Spontaneous regression of diffuse tracheobronchial amyloidosis. Chest 1979; 76: 237 - 239

8 O'Regan A, Fenlon HM, Beamis JF Jr et al. Tracheobronchial amyloidosis. The Boston University experience from 1984 to 1999. Medicine (Baltimore) 2000; 79: 69-79

9 Paccalin M, Hachulla E, Cazalet $C$ et al. Localized amyloidosis: a survey of 35 French cases. Amyloid 2005; 12: 239-245

10 Neben-Wittich MA, Foote RL, Kalra S. External beam radiation therapy for tracheobronchial amyloidosis. Chest 2007; 132: 262 - 267

11 Leigh BR, Kurtts TA, Mack CF et al. Radiation therapy for the palliation of multiple myeloma. Int J Radiat Oncol Biol Phys 1993; 25: 801 - 804 